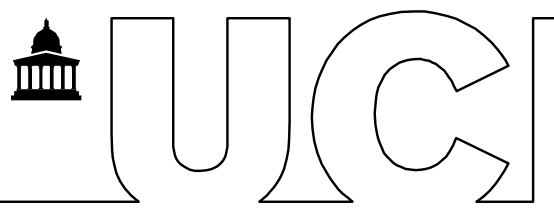

KORNER, A; (2011) The Experience of Time as Crisis. On Croce's and Benjamin's Concept of History. Intellectual History Review , 21 (2) 151 - 169. Downloaded from UCL Discovery: http://discovery.ucl.ac.uk/1321530

\title{
ARTICLE
}

\section{The Experience of Time as Crisis. On Croce's and Benjamin's Concept of History}

\author{
Axel Körner, UCL History Department, University College London
}

\begin{abstract}
In the early decades of the twentieth century the experience of time as crisis became the catalyst for a fundamental reorientation in the relationship between historical materialism and idealism, leading to the rejection of simplistic mechanical concepts of historical time. This reorientation represents a turning point in the history of European ideas, clearly evident in the work of two major thinkers of this period, usually associated with opposing political ideologies: the Marxist theorist Walter Benjamin and the liberal philosopher Benedetto Croce. Based on a conceptual framework borrowed partly from Reinhart Koselleck, this article explains how the experience of acute crisis led both thinkers to develop a new understanding of historical time, which shows surprising parallels. Both authors used the reorientation in the relationship between idealism and materialism to criticize positivist approaches to the analysis of historical change and to reject deterministic accounts of the future.
\end{abstract}

Keywords: Benedetto Croce, Walter Benjamin, Reinhart Koselleck, Crisis, Semantics of Historical Time

Modernity and modern time are experienced as change, change offering opportunities or presenting threats - positive or negative challenges. Since the late eighteenth century and throughout the Age of Revolution most European and American observers experienced modernity as an acceleration of time. Towards the end of the nineteenth century continuously increasing levels of modernity culminated in the consciousness of crisis which is widely associated with the Fin-de-siècle. This crisis was followed by the collapse of the Old Europe during World War One, the totalitarian dictatorships and the genocides of the interwar period, the Second World War, and the Shoah.

Shortly before his suicide in 1942 Stefan Zweig described his experience of the present as the end of "yesterday's world". Thomas Mann, Friedrich Meinecke and others used the term catastrophe to articulate how they experienced the end of their 
life worlds. ${ }^{1}$ In this context probably the most famous reference to the experience of time as catastrophe can be found in Walter Benjamin's last manuscript of 1940 (first published posthumously as a special issue of the Zeitschrift für Sozialforschung in 1942), Über den Begriff der Geschichte. ${ }^{2}$ What many of these descriptions have in common is the reference to a specific semantic of historical time. At the core of this experience is the consciousness of a constant acceleration with which the old world approaches its own end, a process to which humankind is completely subjected. This acute crisis was experienced as the coming of an apocalyptic moment, the end of time. There is only one way of making sense of this fear of Endzeit, which is to imagine the experience of one's own death. End of time becomes meaningful through the fear of and the confrontation with death. This feeling is the source of despair when being subjected to the acceleration of time towards the end of time itself.

In his famous entry on the concept of Kritik in Historische Grundbegriffe, Reinhart Koselleck pointed to the term's bipolar semantic significance in social and political language as "criticism" and "crisis" (Kritik and Krise). Investigating the concept's historical meaning and its role in social and political language, Koselleck demonstrated how humankind articulated the experience of modernity as a change in

${ }^{1}$ See for instance W. Wippermann, "Deutsche Katastrophe. Meinecke, Ritter und der erste Historikerstreit", in: Friedrich Meinecke in seiner Zeit. Studien zu Leben und Werk, eds G. Bock / D. Schönpflug (Stuttgart: Steiner, 2006), 177-191.

${ }^{2}$ W. Benjamin, Über den Begriff der Geschichte, in: Gesammelte Schriften (Frankfurt / M.: Suhrkamp, 1991), I.2: 691-704. For an English edition see W. Benjamin, Selected Writings, 4: 1938-40 (Cambridge: Harvard University Press, 2003). On the work’s origin see R. Tiedemann and H. Schweppenhäuser, “Anmerkungen der Herausgeber”, in: W. Benjamin, Gesammelte Schriften, (Frankfurt /M.: Suhrkamp, 1991), 1/3: 1223-66. Benjamin wrote Über den Begriff der Geschichte in 1940; some sections have been drafted as part of an article on Eduard Fuchs in 1937. On the edition of Benjamin's works see also R. Tiedemann, “Epilegomena zur BenjaminAusgabe", in: idem., Dialektik im Stillstand. Versuche zum Spätwerk Walter Benjamins (Frankfurt / M.: Suhrkamp, 1983), 145-194. 
the semantic of historical time. ${ }^{3}$ In the early decades of the twentieth century the articulation of this experience as crisis became the catalyst for a fundamental reorientation in the way some critical observers understood the relationship between historical materialism and idealism, forming the basis for a new conceptualisation of their own experience of historical time. This reorientation, as well as the role of the experience of crisis within this process, represents a major turning point in the history of European ideas. While other commentators have noticed that particular thinkers during this period reconfigured the relationship between materialism and idealism, they ignored the extent to which this shift originates in a specific experience of time. Moreover, historians of $20^{\text {th }}$-century European thought tend to look at these thinkers in isolation and according to pre-defined schemes of classification along ideological or political lines. As a consequence, they have neglected the extent to which this shift represents a general phenomenon which allows us to see communalities between thinkers whom we would otherwise not discuss in relation to each other.

The reorientation in the relationship between materialism and idealism is clearly evident in the work of two major European thinkers of this period, usually associated with opposing political ideologies: the Marxist theorist Walter Benjamin and the liberal philosopher Benedetto Croce. Croce's philosophy had a major impact on the work of Antonio Gramsci as well as on the ideological orientation of important strands of the Italian Resistance, in particular the movement Giustizia e Libertà. Benedetto Croce was an international icon of anti-Fascism and widely considered Europe's most influential philosopher during the first half of the twentieth century. It is largely due to the political developments of the post-war period (and partly to his own rather unfortunate explanation of the origins of Italian Fascism) that Croce's role within European philosophy diminished since the 1950s (at least internationally). Academia turned away from idealist conceptions of history and new directions within Marxist

${ }^{3}$ R. Koselleck, "Crisis", Journal of the History of Ideas 67, 2, (April 2006): 357-400.

The article is the translation of Koselleck's own entry in Geschichtliche

Grundbegriffe: Historisches Lexikon zur politisch-sozialen Sprache in Deutschland.

eds O. Brunner, W. Conze, R. Koselleck (Stuttgart: Klett-Cotta, 1972-1997). The

entry itself goes back to a footnote in R. Koselleck, Kritik und Krise. Zur Pathogenese der bürgerlichen Welt (1959) (Frankfurt / M: Suhrkamp, 1992). On the "apocalyptic dynamics in modern political religions" see Eric Voegelin, The Political Religions (1938), in The Collected Works of Eric Voegelin. Vol.5: Modernity without Restraint (Manfred Henningsen, ed.). Columbia, London: University of Missouri Press, 2000, $19-73,51 \mathrm{f}$. 
theory left little space for his ideas. The interest of the English-speaking world in Antonio Gramsci since the 1970s did not lead to a renaissance of Croce's thought.

The reception of Benjamin's thought worked the other way round. At the time of his death only a few specialists knew his work and early editions of his fragmentary writings rarely reached more than a few hundred readers. When Peter Suhrkamp, with the help of Theodor and Gretel Adorno, edited in 1955 the first two volumes of essays by Benjamin, he found only 816 buyers for the edition, of a print-run of $2,300 .{ }^{4}$ During the 1950 s and early 1960 s ideological and theoretical debates in scholarship hardly touched upon Benjamin's work. The renaissance of Benjamin started in the second half of the 1960s with the publication of selected works in German, and took off in the 1970s when the first volumes of the critical edition started to appear. Then, apart from the more specialized discussion by scholars of Jewish thought, debate on Benjamin was for a long time restricted to Marxist theorists, before his work gained an important basis among literary scholars, art

${ }^{4}$ S. Unseld, "Walter Benjamin and the Suhrkamp Verlag", in For Walter Benjamin, eds I. and K. Scheuermann (Bonn: AsKI, 1993), 12-14. 
historians and cultural theorists. It took until 1982 to complete the German edition of the Passagen-Werk, which then sold 700,000 copies within the first decade. ${ }^{5}$

Scholarship ignores that Croce's and Benjamin's observations on philosophy of history, and their impact on European thought as a whole, have a common source, which is the two authors' specific experience of their own time as crisis. There are also important parallels to Koselleck's (and to some extent Gadamer's) work on the semantics of historical time, even if Koselleck does not relate his own theories to either Croce or Benjamin. ${ }^{6}$ One can identify a bridge between Croce's and

${ }^{5}$ ibid. For an overview of 80 years of debate on Benjamin see Walter Benjamin.

Critical evaluations in cultural theory, ed. P. Osborne (London: Routledge, 2005). Also Materialien zu Benjamins Thesen 'Über den Begriff der Geschichte'. Beiträge und Interpretationen, ed. P. Bulthaup (Frankfurt /M.: Suhrkamp, 1975). I do not intend to take position in the polemical debates which characterised the different strands of the German reception during the 1970s and 1980s. See for instance Walter Benjamin. Profane Erleuchtung und rettende Kritik. eds N. W. Bolz and R. Faber (Würzburg: Königshausen \& Neumann, 1982). C. Hering, Die Rekonstruktion der Revolution. Walter Benjamins messianischer Materialismus in den Thesen Über den Begriff der Geschichte (Frankfurt: Peter Lang, 1983), 9 ff. On the origins of the ideological divisions which characterised the reception of Benjamin see J. Habermas, "Bewußtmachende oder rettende Kritik - die Aktualität Walter Benjamins", in Zur Aktualität Walter Benjamins, ed. S. Unseld (Frankfurt / M.: Suhrkamp, 1972), 173$223,175 \mathrm{ff}$.

${ }^{6}$ The reason for this is probably that from the mid-1930s, due to political reasons, Croce was largely ignored in German academia. Gadamer refers to Croce's translator Collingwood, but not to Croce himself. An important connection between the concepts of historical time in Benjamin, Croce and Koselleck might be Heidegger, but this would require further research. See in this context H. Caygill, "Benjamin, Heidegger and the Destruction of Tradition", in Walter Benjamin's Philosophy. 
Benjamin's thought in the work of Arnaldo Momigliano, who was deeply influenced by Croce and his concept of history as the history of freedom, but who also worked closely with Benjamin's intimate friend and his most influential commentator, Gershom Scholem. ${ }^{7}$ However, Momigliano referred to Benjamin only briefly and although he frequently comments on the influence of Croce in his writings, his references to the philosopher's theory of history are usually implicit rather than explicit. ${ }^{8}$ What I wish to suggest by connecting these different thinkers to the work of Croce and Benjamin is that Croce's and Benjamin's thought on the semantics of historical time had a much wider impact then previously recognised, but that this presents a constellation which as yet has not been sufficiently explored.

In the following, I will explain how the critical experience of a shift in the meaning of historical time led both Croce and Benjamin to the development of a new concept of history, which shows surprising parallels. Since the 1920s both men witnessed how different political ideologies attempted to reduce historical time to a deterministic prism, which allowed totalitarian regimes to manipulate society into an inescapable logic of a future-oriented historical processes. While Croce refers in his critique mostly to the futurist ideology of the Fascist regimes, Benjamin's target is the

Destruction and Experience. eds A. Benjamin, P. Osborne (London: Routledge,

1994), 1-31. Hannah Arendt was one of the first recipients of Benjamin's manuscript, but she left no detailed commentary on the work.

${ }^{7}$ Koselleck mentions Momigliano only briefly: R. Koselleck, Zeitschichten. Studien zur Historik (Frankfurt / M.: Suhrkamp, 2000), 19. Momigliano acknowledged Benjamin's influence on Scholem in his review of Scholem's memoirs. Michael Hamburger, "Scholem and Benjamin”, Grand Street I, 4 (Summer 1982): 128-37. See in this context also Momigliano and Antiquarianism. Foundations of the Modern Cultural Sciences, ed. P. N. Miller (Toronto: University of California, 2007). ${ }^{8}$ A. Momigliano "Benedetto Croce" (1950), in: idem, Nono Contributo alla Storia degli Studi Classici e del Mondo Antico (Rome: Ed. di Storia e di Letteratura, 1992), 531-41. See also C. Dionisotti, “Arnaldo Momigliano e Croce”, Belfagor XLIII (1988): 617-42. Momigliano's most important contribution to the study of historical time is A. Momigliano, "Time in Ancient History", History and Theory Bh.6 (1966): $1-23$. 
international Labour movement and its passive attitude to Fascism. Through their respective analysis of the underlying circumstances Croce and Benjamin attempted to dismantle the conceptual incoherence of historical determinism and to free humankind from misunderstood philosophies of history. This article argues that overcoming the opposition between idealism and materialism presents the key to their new concept of historical time. In the following I will first discuss Benjamin, before relating his concept of history to that of Croce. This is despite the fact that most of Croce's works on this problem were written before Benjamin's manuscript Über den Begriff der Geschichte and that Benjamin was aware of Croce and commented on some of his work. However, chronology is not directly relevant to my argument and I wish to avoid giving the impression that I understand Benjamin's position as directly influenced by Croce. Benjamin himself explained in a letter to Gretel Adorno that his manuscript Über den Begriff der Geschichte contained thoughts which he had kept to himself for over twenty years, before writing them down. ${ }^{9}$ Hence, to some extent his thought even predates Croce's, although it was the experience of exile and captivity which led him to conceptualize these ideas. My main concern here is to understand the reorientation in the relationship between idealism and materialism as a consequence of the experience of crisis, which Benjamin articulates even more emphatically than Croce. ${ }^{10}$

As Koselleck reminds us, in classical Greek the concepts critique and crisis were represented by the same term, the former describing a subjective process, the latter an objective state. In its historical use the term had either a medical or a religious connotation, but containing the possibility of salvation. Crisis anticipates in its ultimate and most extreme form the end of the world and will reveal justice. The Last Judgment is a crisis, in the sense of judicium, where the promise of salvation, of eternity and of a life after the end of time presents a fundamental aspect of the eschatological concept. Considering any historical notions of the end of time we have to consider the extent to which these concepts are embedded in Western culture and more generally in monotheistic traditions of thought.

The sister concepts of critique and crisis, and the consciousness of a dramatic change in the semantic of historical time during the first half of the twentieth century, are at the center of the reorientation in the relationship between historical materialism and idealism, which this article wishes to discuss. There are a number of key texts which form the basis for my argument and which are considered here within the wider context of their authors' work. These texts are Benjamin's last manuscript Über

\footnotetext{
${ }^{9}$ Tiedemann and Schweppenhäuser, “Anmerkungen der Herausgeber”, 1223.

${ }^{10}$ Despite the tragic circumstances under which Benjamin wrote his manuscript, the initial catalyst for the new semantic of historical time was the Great War: M. Jay, "Walter Benjamin, Remembrance and the First World War", in Walter Benjamin, ed.
} Osborne, 2: 230-49. 
den Begriff der Geschichte and Croce's Antistoricismo as well as his Storia d'Europa. Another text relevant to this discussion is Gramsci's II materialismo storico e la filosofia di Benedetto Croce.

Empirically explored in Ursprung des Deutschen Trauerspiels and the fragments of the Passagen-Werk, but conceptualized in Über den Begriff der Geschichte, Benjamin rejects the deterministic illusion of a linear concept of time as it was formalised in the idea of a progress-oriented philosophy of history since Hegel. ${ }^{11}$ The following presents a synthesis of his Über den Begriff der Geschichte, privileging those aspects of the text which are mostly relevant for the argument of this article.

In Über den Begriff der Geschichte Benjamin describes the concept of time inherent in the logic of historical materialism as a positivist illusion (I, VI). The future (including the promise of salvation) is constructed out of a contemporary present, in the same way in which the past (with its own futures) is constructed through the present. The basis of the materialist's future is the narration of a particular past. The materialist - as well as his or her object of study - is determined by ideas, by a specific idea of future time. (II and IV) In thesis VI Benjamin presents us with a materialist and dialectic account of the Last Judgement: "the Messiah comes not only as the Redeemer", but "to overbear the Antichrist". What this means with regard to concepts of past and future becomes clearer in thesis IX, where Benjamin refers to Paul Klee's painting Angelus Novus, which had been in his possession since 1921. Reflections on Klee's angel had become a key element in Benjamin's thought and a catalyst for his revision of historical materialism. In Benjamin's interpretation the angel is walking backwards and stares with wide open wings at a past from which he moves away.

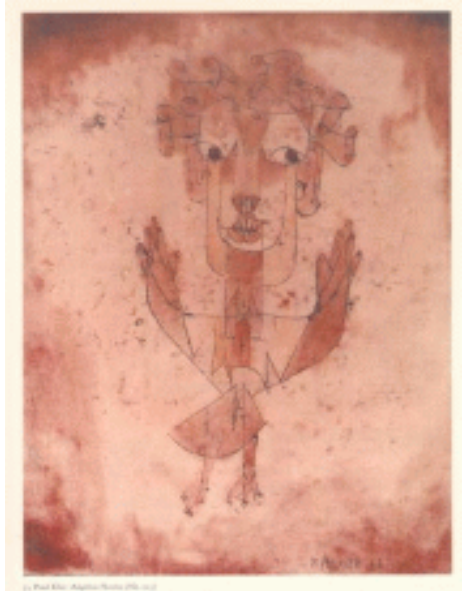

Benjamin describes Klee's angel as the angel of history, who knows that there is eternal life. What humankind perceives as a chain of past events

${ }^{11}$ See in particular the important work by S. Mosès, Der Engel der Geschichte. Franz Rosenzweig, Walter Benjamin, Gerschom Scholem (Frankfurt /M.: Jüdischer Verlag, 1994), chpt.5 and 134 f. Benjamin, Über den Begriff der Geschichte. 
which determine a particular future, the angel sees accumulating into catastrophe, with no connection to the projected and artificially constructed future. The angel's wings are blown up by the storm of time, which originates from paradise. This storm is what we call and perceive as progress. In the following Benjamin provides us with a contemporary political reading of this image $(\mathrm{X})$.

The politicians, in whom the opponents of Fascism had put their hopes, have either betrayed their own ideals or they were destroyed by the present constellation of power. Benjamin holds their stubborn belief in progress responsible for the current conditions. The socialists' belief that the development of the productive forces will inevitably lead to socialism presents an illusion, which allowed the dominant classes to maintain and extend their power. Moreover, the technocratic logic of modernisation, which is inherent in the socialists' idealisation of labour and forms a crucial element in their deterministic view of history, shares common ground with Fascism. (XI) The strength of historical materialism lies in the fact that it recognized the existence of a working class and the role it may play in the historical process. The problem, for Benjamin, is not the materialist base, the role assigned to the forces of production in determining the present, but the philosophies of past time associated with these facts. Despite its insights in the societal power relations, the Labour movement abandoned the idea to free the working class in the present, assigning this role to future generations. It sacrificed its power and as a consequence the working class lost its role in the present. (XII) Therefore, the Labour movement's error is its blind belief in the historical progress of humanity, which paralysed it for the present. (XIV) History is always subjectively constructed in the present. For Robespierre, Ancient Rome was a past of his own present, which he separated from historical continuity. ${ }^{12}$ The French Revolution became the new Rome. Another example Benjamin evokes is fashion, which makes reference to past costumes, jumping into a past from a position which is circumscribed by present power relations. Marx understands revolution in exactly the same way, as a dialectic movement which separates the revolutionary future from the continuum of the past, as a moment of complete rupture, symbolized by the introduction of new calendars to document the revolutionary acceleration of historical time. (XIV, XV) Materialist historiography consists in identifying a revolutionary opportunity in a particular future and separating it from its historical continuum. (XVII)

Über den Begriff der Geschichte rejects the Labour Movement's blind belief in progress and outlines the shortcomings of a historical materialism based on the

${ }^{12}$ On Benjamin's concern for the proximity of revolutionary and reactionary thought see also E. Traverso, La pensée dispersée. Figures de l'exile judéo-allemand (Paris: Lignes, 2004), $41 \mathrm{f}$. 
deterministic conviction of the revolution's inevitability. It is this constellation of historical time which paralysed the working class for the present. The materialist basis of the socialists' concept of time gives the revolutionary future an aura of positive reality, but this constructed reality leads to an illusion. Blinded by this illusion and helplessly awaiting the realisation of its future, humankind runs into catastrophe, the catastrophe which Benjamin himself witnessed since the outbreak of the Second World War.

Scholem described the theses outlined in Über den Begriff der Geschichte as the result of Benjamin's "awakening from the shock of the Hitler-Stalin pact", ${ }^{13}$ which better than anything represents what the revolutionary movement had become. For Benjamin this was a personal revelation, but also a catalyst to rethink his understanding of historical materialism. From a theoretical point of view Benjamin had abandoned the rigidity of historical materialism already two decades earlier. His interest in Marxist theory remained limited and much of his work since the 1920s pays witness to a much more flexible understanding of the past. ${ }^{14}$ The fact that he finally conceptualized his thoughts during his unsuccessful attempt to escape from Hitler's Europe is in itself significant. This was Benjamin's most acute realisation of time as crisis. But when the gendarmerie at Portbou stopped him in the Pyrenees, we do not know if Benjamin abandoned his hope that humanity might overcome the deterministic illusion of this manipulated future. It is a matter of uncertainty if Benjamin committed suicide in Portbou or if his death was an accident. ${ }^{15}$

Benjamin's concept of Eingedenken, the contemplation of an open past in the present, has a strong theological component and shows similarities to Franz Rosenzweig's attempted synthesis of theology and philosophy. ${ }^{16}$ It also represents a

${ }^{13}$ G. Scholem, "Walter Benjamin und sein Engel”, in Zur Aktualität, ed. Unseld, 87-

138, 129. See also Tiedemann, "Historischer Materialismus oder politischer

Messianismus?”, 278 ff. Hering, Die Rekonstruktion, 16. F. Voßkühler, Kunst als Mythos der Moderne (Würzburg: Königshausen\&Neumann, 2004), 293. Mosès, Der Engel, 88 .

${ }^{14}$ Benjamin introduces the famous ninth thesis about the Angel with a quote from a poem by Scholem, which he had received for his birthday in 1921 and which pays witness to the long history of their debates on the topic.

${ }^{15}$ See in particular the essays in For Walter Benjamin.

${ }^{16}$ The theological dimension in Benjamin's work was first analysed by Scholem,

"Walter Benjamin und sein Engel”. Scholem introduced Benjamin to Rosenzweig and 
strongly subjective and idealist component in Benjamin's thought. But contrary to Gershom Scholem's hopes of the 1930s and despite Benjamin's early interest Jewish mysticism, Benjamin's principal objective in Über den Begriff der Geschichte was not a translation of Jewish mysticism into an idiom of the modern age. ${ }^{17}$ Instead, his target was the concept of historical time which determined the policies of the Labour movement, a critique generated by his own experience of crisis. The concept of historical time which Benjamin developed in this critique contained theological elements, but there also remains a strong materialist foundation. As Abraham Socher explains, when Scholem dedicated Major Trends in Jewish Mysticism to Benjamin it "was an act of disappointment as well as mourning". ${ }^{18}$ In the opening of Ursprung des deutschen Trauerspiels Benjamin employed a Kabbalistic text to illustrate his idea of the origin of words; but in earlier versions of the passage there is evidence to suggest that he might have misunderstood the passage he was referring to. His projects to learn Hebrew were abandoned and in his later writings direct references

he later claimed that his work had appealed to him: G. Scholem, Walter Benjamin.

The Story of a Friendship (New York: NYRB, 2003), 124, 167. On Scholem's influence on Benjamin see also idem, Walter Benjamin und sein Engel. Vierzehn Aufsätze und kleine Beiträge (1967) (Frankfurt / M.: Suhrkamp, 1992) and R. Alter, Necessary Angels. Tradition and Modernity in Kafka, Benjamin and Scholem (Cambridge, Mass.: Harvard UP, 1991).

${ }^{17}$ See for this debate A. Socher, "Revelation in the rock. Walter Benjamin, Gershom Scholem and the stones of Sinai”, Times Literary Supplement, 21 March 2008, 13-15. In what follows it is not my intention to deny the theological dimension in Benjamin's work. For a general discussion of the relationship between Messianism and Materialism in Über den Begriff der Geschichte see R. Tiedemann, "Historischer Materialismus oder politischer Messianismus. Annäherung an die Thesen 'Über den Begriff der Geschichte"” (1975), in: idem., Mystik und Aufklärung, 254-298. See also R. Dieckhoff, Mythos und Moderne. Über die verborgene Mystik in den Schriften Walter Benjamins (Köln: Janus, 1987), 12 f; on the cabbalistic references in Benjamin, idem, $26 \mathrm{ff}$.

${ }^{18}$ A. Socher, "Revelation in the rock", 13. 
to Jewish mysticism are less obvious, despite the Messianic elements in his concept of history. What the materialist conception of history shares with theology is the concept of utopia, here more specifically the memory of the lost paradise or the reign of freedom in a Marxist sense. For both it is a promise, which helps believers not to despair in face of the present past. ${ }^{19}$ Meanwhile, this future retains a dialectic dynamic. In thesis VI Benjamin explains that "the Messiah comes not only as the Redeemer", but "to overbear the Antichrist". As Tiedemann has demonstrated, nowhere in this work "Benjamin talks more instantaneously theologically, nowhere is his intention more materialist." ${ }^{20}$ The antichrist is the ruling class, the Messiah its opponent in the class struggle.

Since the 1980s Benjamin was occasionally read as an apostle of postmodernism. ${ }^{21}$ However, his insistence on multiple structures of time, each with their own past, present and future, is not meant to result in an arbitrary interpretation of historical time. The fact that Benjamin expanded the material basis of his philosophy of history to include cultural production and psychological phenomena, and that he employs a specific theological and metaphysical tradition to explain changes in the semantic of time, does not mean that he rejected all principles of historical materialism or that he understood the theological component of his thinking as a contradiction of its materialist base. Instead, the theological dimension of his thought indicates a fundamental anthropological experience in the process of cognition which for Benjamin became an asset helping him to refine historical materialism.

More than a purely theoretical conceptualisation, Benjamin's last manuscript reflects an existential experience of time at a specific moment in European history. Benjamin witnessed the 1930s as an acceleration of time towards a catastrophic end, moving at a speed which blows into the wings of his angel. The total catastrophe which Benjamin's angel faced and from which he seems to retreat stood for an eschatological concept of crisis. However, historically the coming of this cosmic crisis is anticipated by the knowledge of redemption, which grants eternal life. This is the element of hope in Benjamin's interpretation of Klee's messenger, who stares into the catastrophe of history, but knows about the Adamic paradise.

The theological dimension in Benjamin's work is more than symbolic. It stands for the agency of ideas, countering the determinism of the current ideologies of history. The crisis is objective; his criticism, nurtured by the consciousness of past time, is subjective, positioned conceptually against the historical determinism of his age. ${ }^{22}$

\footnotetext{
${ }^{19}$ Tiedemann, "Historischer Materialismus oder politischer Messianismus”, 259.

${ }^{20}$ Tiedemann, "Historischer Materialismus oder politischer Messianismus", 272.

${ }^{21}$ Mosès, Der Engel, chpt.5 and 134 f.

${ }^{22}$ On a philosophical level Benjamin's thought contrasts strongly with Ernst Bloch's

Messianic Marxism: H. Mayer, Ein Deutscher auf Widerruf. Erinnerungen (Frankfurt
} 
Using Koselleck's terminology, the theological dimension in Über den Begriff der Geschichte can be understood as an example of Verzeitlichung, as a "new temporal horizon". ${ }^{23}$ What Benjamin's Angelus Novus confronts is exactly such a moment of crisis, "the apocalyptical foreshortening of time that precedes the Last Judgment", the cosmological idea of God as the master of time, but used here in a secularmetaphorical sense. Under the impact of his own existential experience of time Benjamin understands historical progress as the catastrophe itself, which he wishes to void by pulling the emergency break and freeing the present from its historicalsemantic cage.

At the root of his cognitive experience is his own remembering of the past, an idealist moment, which provokes in him a new consciousness of historicity and which can be compared to Marcel Proust's concept of remembering le temps perdu. (He developed this concept in connection with his research for the Passagen-Werk and his translations of Proust.) For Benjamin, this particular form of historicity is an instance evoked against the fatal linearity of historical time. It also restores an idealist dimension into the conception of time. In his critique of materialist teleology Benjamin identifies a problem which less than a generation later, and still under the impact of the same catastrophe, Koselleck described in Kritik und Krise as the pathogenesis of the bourgeois world. For Benjamin, like for Koselleck, the fatality of historical determinism is behind the social dynamic which characterizes the rise of the totalitarian dictatorships and which leads the masses to accept their political regimes as the inevitable logic of a historical development. ${ }^{24}$ Benjamin's own dynamic view of historical time, according to which each present has its own past and future, is directed against the same fatal illusions.

Benjamin's angel is a reference to the idea of eternity and to a specific Jewish tradition, which survived in Christian thought and which Romanticism had liberated from scholarly dogmatism, making it an almost secularised cultural concept. His concept of crisis develops out of the enlightenment use of the term, positioned against the idealist philosophy of history of the post-enlightenment, which was at the basis of the major ideological currents and the totalitarian regimes of the early

/ M.: Suhrkamp, 1984), 2: 292 f. Also P. Osborne, "Small-scale Victories, Large-scale

Defeats. Walter Benjamin's Politics of Time”, in Walter Benjamin's Philosophy, eds

Benjamin / Osborne, 59-109, 62.

${ }^{23}$ Alter, Necessary Angels. M. and M. Richter, "Introduction: Translation of Reinhart Koselleck's Krise in Geschichtliche Grundbegriffe", Journal of the History of Ideas 67/2 (April 2006): 343-56, 350.

${ }^{24}$ See in particular R. Koselleck, Kritik und Krise. 
twentieth century. ${ }^{25}$ Rejecting the degeneration of enlightenment thought into a deterministic philosophy of history, Benjamin's Rückbesinnung on the concept of critique/crisis becomes an instance capable of stopping humanity's march into catastrophe. His idea of eternity contradicts any determinist conception of history.

Benjamin arrives at this conception analytically, through knowledge of theological concepts, as a scholar of literature and through the observation of his own time. The theological concept works here as an anthropological Urphänomen, a basic human experience of recognition. As Joseph Mali has argued, Benjamin understands Ursprung "in genealogical rather than biological terms, contending that it was not to be found in the moment of intuition but rather in that of recognition". ${ }^{26}$ For Benjamin the basis of this recognition is myth; in Habermas' words it constitutes "the semantic potential from which human beings draw" ${ }^{27}$ The theological dimension and the role of redemption in his concept of time are part of Benjamin's mythological perception of reality, part of humanity's ancient hopes and dreams. Myths offer "a reservoir of meanings" (Koselleck), explored as a source of strength and happiness. ${ }^{28}$ They constitute part of the Erwartungshorizont, which is historical in so far as it impacts on the present within the stream of historical time.

The materialist dimension of Benjamin's concept of time lies in the fact that history is the history of class struggle: a dialectical process. Also redemption, for Benjamin, is not idealist but materialist. "As fighter in the class struggle", Gerhard Kaiser explained in his comment on Benjamin, "man is the subject of history", but in the realm of ideas he is also "object of the redemption", which represents the end of history altogether, understood as an idea rather than a historical fact. ${ }^{29}$ Instead of considering dialectic as automatically leading to victory, it is a materialist struggle with an open end. What

${ }^{25}$ Rousseau and Herder used the term crisis against an optimistic and simplistic faith in perpetual progress: Koselleck, "Crisis", 372, 376.

${ }^{26}$ Joseph Mali, “The Reconciliation of Myth: Benjamin's Homage to Bachofen”, in:

Journal of the History of Ideas, 61/1 (1999), 165-187, 166.

${ }^{27}$ J. Habermas, quoted in Mali, "Benjamin's Homage to Bachofen", 167.

${ }^{28}$ R. Koselleck, Vergangene Zukunft. Zur Semantik geschichtlicher Zeiten (Frankfurt /

M.: Suhrkamp, 1989), 38-66. For an anthropological approach see R. Schlesier,

"Mythos", in: C. Wulf, ed., Vom Menschen. Handbuch Historische Anthropologie

(Weinheim / Basel: Beltz, 1997), 1079-1086.

${ }^{29}$ G. Kaiser, "Walter Benjamins Geschichtsphilosophische Thesen", in: Materialien, ed. Bulthaup, 43-76, 46. 
Messianic tradition understands as divine intervention is for Benjamin human recognition of time. This constitutes a Messianic moment - symbolised by the angel as a messenger of God - but redemption itself is not beyond human power as long as the recognition of time itself is a human act. Redemption is part of a man made history, in the sense of Vico. ${ }^{30}$ Man's messianic power lies in the fact that he is the subject of the historical process and has the capacity to resist philosophy of history. This subjectivity represents the idealist dimension of Benjamin's concept of historical time. Benjamin's is a philosophy of praxis, like that of Croce and Gramsci.

As Stéphane Mosès has demonstrated, for Benjamin it is the role of the materialist historian to recover relics of auratic experience, elements of a past, original truth, somewhere hidden in our modern and profane world. ${ }^{31}$ This is what Benjamin himself does in his work as historian, when he understands the Paris of his time as one of a specific historicity, specific to his own present, the present he observes. The revolutionary historian reveals the dimension of the new in history, without applying principles of causality. Thus, history becomes political; the present becomes judgment. Not unlike Koselleck's understanding of historical time, history is not universal but present, comparable to the way in which art, for Benjamin, is never historical, but always new: no work is just the response to another work, but product of a creative genius. For Hegel history is the judge over time; for Benjamin it is the present, which reveals its own history. ${ }^{32}$ Benjamin's temporality is therefore discontinuous, polycentric, and consequently opposed to determinism and the illusion of progress. As Mosès argues, in Benjamin past, present and future are specific conditions of the historical consciousness. ${ }^{33}$

A very similar idea of historical consciousness also presents the key to Benedetto Croce's theory of history. For two reasons Benjamin's concept of historical time is closely related to that of Croce. Like Benjamin, Croce acknowledges the role of material forces in history, but questions the opposition between materialism and idealism, which becomes the basis for his critique of a positivist and deterministic understanding of historical time. And like Benjamin, he arrives at this position through a critique of the future-oriented discourse on the semantic of time, which marked the ideological and political climate of the interwar period.

\footnotetext{
${ }^{30}$ See here in particular the relationship between Vico and subsequent philosophies of history: R. Tiedemann, "Studien zur Philosophie Walter Benjamins" (1965) in: idem., Mystik und Aufklärung. Studien zur Philosophie Walter Benjamins (München: edition text + kritik, 2002), 9-176, $141 \mathrm{f}$.

${ }^{31}$ Mosès, Der Engel, 109.

32 ibid., 140.

${ }^{33}$ ibid., 148.
} 
Croce's idealism was originally conceived as an antidote to the positivism which reigned in Italian academia during the late nineteenth and early twentieth century. While Norberto Bobbio has demonstrated that positivism hardly presented a serious philosophical position in Italy, it definitely marked the social sciences since the turn of the century, with an important direct impact on major political ideologies. ${ }^{34}$ As Momigliano explains, even in the arts and humanities positivism left its traces: "About 1890 academic students of history or literature were often recommended to confine themselves to facts in the hope that later on perhaps all the facts could be interpreted by some general law - which would be the key to the understanding of history and art." ${ }^{35}$ The Italian reception of Darwin played an important role in this development, first translated in 1864 by the Bolognese publisher Zanichelli, in the former Papal States, at a time when the old University of Bologna became the Mecca of new scientific approaches to knowledge. Italian liberal and socialist thought made explicit reference to social Darwinism and a handbook of socialist propaganda published in the 1890s advised its readers to first engage with Spencer and Darwin, before completing the triad with Marx. ${ }^{36}$

At the end of the century a decisive reaction against simplistic social theories emerged in Italian academic debate. Endorsed by Croce, the Socialist Antonio Labriola was among the first to reject a positivistic interpretation of Marx. As Bobbio has argued, Croce's "idealist reaction against positivism changed not only the general concept of philosophy but also the taste, the style and the affections and disaffections of an entire cultural epoch. (...) Positivism had sought to give a naturalist explanation even of manifestations of the spirit; idealism, repudiating all forms of naturalism, sought to give a spiritualist explanation even of natural phenomena." ${ }^{37}$ Croce set out to bring positivism and idealism back into balance and with regard to concepts of time he argued that the future is contingent on the creative ideas and actions of individuals in the present.

The way in which Croce rethinks the relationship between idealism and materialism makes it almost impossible to reduce his contribution to that of introducing Italians to

\footnotetext{
${ }^{34}$ N. Bobbio, Ideological Profile of Twentieth-Century Italy (Princeton: Princeton

University Press, 1995), 5 ff.

${ }^{35}$ Momigliano, "Benedetto Croce”, 536.

${ }^{36}$ Bobbio, Ideological Profile of Twentieth-Century Italy, $5 \mathrm{ff}$. He refers here to
}

Ferri's Socialismo e scienza positiva of 1894 . On the impact of Darwin see also

Körner, Politics of Culture, chpt.5.

${ }^{37}$ Bobbio, Ideological Profile, 70. 
Hegel, as some commentators have done. ${ }^{38}$ Part of his turn against a deterministic understanding of history is rooted precisely in his critique of the teleological dimension of Hegel's philosophy. As Croce explains in the epilogue to his Storia d'Europa of 1931,

"Those who, contrary to the ancient warning of Solon, endeavour to understand and judge a life 'before it is ended' and who are lost in conjectures and previsions, should be beware lest this divagation into what it is impossible to know be not in fact the prompting of an evil demon, who is cradling them in indolence and distracting them from the task.

Not the 'history of the future' (as the old writers used to define prophecy), but that of the past which is epitomized in the present, is necessary for work and for action - which would not be real action if it were not illumined by the light of truth." ${ }^{39}$

Croce refers here explicitly to the ideological implications of contemporary attempts to manipulate historical time, in particular the attempts of Futurists and Fascists. In his Antistoricismo, a paper of September 1930 read at the Seventh International Congress of Philosophy in Oxford, Croce criticized the current "decadence of historical sentiment" and the "extreme anti-historical attitude" which characterized the new ideologies and the contemporary political climate. ${ }^{40}$ For Croce, this new antistoricismo appeared under two different forms, one anarchical and one authoritarian, offering an insightful and also rather innovative analysis of these two poles of Fascist ideology. He rejected the Fascists' new futurism as a 'future without past", which "adores force for the sake of force, doing for the sake of doing, the new for the sake of the new, life for the sake of life, a life which doesn't keep a link with the past, because it doesn't wish to be any particular life, but life in the abstract, mere vitality". ${ }^{41}$ The second form of this new antistoricismo loathes "in the very idea of history the reign of relativism and the contingent, of mobility and diversity, of variation and individuality. It hopes for the absolute, for stability, leaving history, transcending

${ }^{38}$ Momigliano "Benedetto Croce", 538.

${ }^{39}$ B. Croce, History of Europe in the Nineteenth Century. trans. Henry Furst (London:

Allen\&Unwin, 1934), 354. For the relationship between materialism and idealism in

Croce see E. Agazzi, "Benedetto Croce. Dalla revisione del marxismo al rilancio

dell'idealismo", in Storia della società italiana. eds Agazzi et al. (Milan: Teti, 1980),

5/9: 279-330.

${ }^{40}$ B. Croce, Antistoricismo (Bari: Laterza, 1931).

${ }^{41}$ ibid., $21 \mathrm{f}$. 
historicism in order to acquire security and peace." ${ }^{42}$ Thus, it becomes stable, uncritical, authoritarian and totalitarian. "With regard to social life, it finds its ideal in an order which suppresses personal initiative, and thus competition and struggle, imposing rules instead." ${ }^{43}$ For Croce, this form of antistoricismo reduces the historical process to just one possible future, denying history's multi-faceted nature.

What becomes clear in Croce's Oxford paper is the extent to which his position articulates his reaction to Europe's recent political and ideological developments. However, his concern is also rooted in the context of wider philosophical debates. Since the turn of the century Italy's critical engagement with positivism, materialism and idealism represented an attempt to reconcile the Italian and European experiences of modernity and to make them meaningful in the context of Italy's Finesecolo crisis, epitomized in Giosuè Carducci's famous dictum that Italy, during its Risorgimento, had hoped for a Third Rome but got Byzantium instead. ${ }^{44}$ Despite this widespread consciousness of crisis, Italy's intellectual debate at the time was characterized by a remarkable cosmopolitanism, which can be traced back to Italy's enlightenment tradition, to the heroic idealism of the Risorgimento and the liberal foundations of the nation state, resulting in a philosophical tradition which made in its time a highly innovative and original contribution to European thought. ${ }^{45}$

\footnotetext{
42 ibid., 23

43 ibid.
}

${ }^{44}$ R. Drake, Byzantium for Rome: the politics of nostalgia in Umbertian Italy, 1878-

1900 (Chapell Hill: North Carolina University Press, 1980).

${ }^{45}$ E. Gentile, The Struggle for Modernity. Nationalism, Futurism, and Fascism

(Westport / London: Praeger, 2003), 47 f. A. Körner, Politics of Culture in Liberal Italy: From Unification to Fascism (New York: Routledge, 2009), chpt.10. M. Af Malmborg, "The Dual Appeal of 'Europe' in Italy”, in The Meaning of Europe.

Variety and Contention within and among Nations, eds idem and B. Stråth (Oxford: Berg, 2002), 51-75, 53. See also R. Grew, “Culture and Society, 1796-1896”, in Italy in the nineteenth century, ed. J. A. Davis (Oxford: Oxford University Press, 2000), 206-34, 207 f. M. Meriggi, "Lo 'Stato di Milano' nell'Italia unità: miti e strategie politiche di una società civile (1860-1945)", in La Lombardia, eds D. Bigazzi and M. Meriggi (Turin: Einaudi, 2001), 5-49, 16. 
Naples, where Croce lived and wrote for most of his life, played an important role in Italy's engagement with European philosophy. Bertrando and Silvio Spaventa (both relatives of Croce), Francesco De Sanctis, Guido de Ruggiero and Benedetto Croce himself tried to connect the emergence of Italy's modern statehood with the principles of Hegel's dialectical philosophy of history and his philosophy of right, understanding the nation's Risorgimento in terms of Hegel's "ethical state", ${ }^{46}$ not dissimilar to the ways in which the Prussian reformers saw their own state develop in the wake of the Napoleonic defeat. They established a philosophical framework for contemporary political and historical debates, which profoundly marked Italy's intellectual life until the middle of the twentieth century and helped to connect Italian thought with the social, political and cultural developments elsewhere in Europe. ${ }^{47}$ In the context of these debates Benedetto Croce's work as philosopher and historian presents a synthetic account of Europe's and Italy's experience of modernity since the Enlightenment. His project culminates in his History of Europe, dedicated to Thomas Mann, where he describes a century during which history no longer appeared "destitute of spirituality and abandoned to blind forces. Now it was seen to be the work and the activity of the spirit, and so since spirit is liberty, the work of liberty." His positive assessment of the nineteenth century is rooted in the author's temporal perspective, writing during the early years of the Italian Fascist regime. His dedication to Mann includes a reference to Dante's Inferno, a passage in which Virgil and Dante find themselves in great danger of being caught by demons - for Croce the demons of the new totalitarian systems, political regimes without history. ${ }^{49}$

${ }^{46}$ G. W. F. Hegel, Grundlinien der Philosophie des Rechts (1820) (Hamburg: Meiner, 1995), $207(\S 257)$.

${ }^{47}$ Italian Modernism. Italian Culture between Decadentism and Avant-Garde. eds L.

Somigli and M. Moroni (Toronto: University of Toronto Press, 2004), 13. For the general context see R. Bellamy, "Social and political thought, 1890-1945”, in Liberal and Fascist Italy. 1900-1945, ed. A. Lyttelton (Oxford: Oxford University Press, 2002), 233-48.

${ }^{48}$ Croce, History of Europe, 9.

${ }^{49}$ Dante, Inferno, XXIII, 28-30. See Arno Schneider, "Eine überaus eindrucksvolle Begegnung: Thomas Mann und Benedetto Croce in München am 28. September 1931", in: Arnaldo Benini and Arno Schneider (eds), Thomas Mann nella storia del suo tempo. Firenze: Passigli Editori, 2004, 341-367, 352 f. 
In the first three chapters of Croce's History of Europe, conceived as a general introduction to the work as a whole, he outlined his idea of "history as the history of freedom". Ideas and passions drove the intellectual, political, social and cultural elites within the various ideological currents of their time - from the church to the liberal movement and including socialist and nationalist ideologies. However, the historical process is not determined by the ideas themselves, but by the social, economic and political structures from which they emerge and which they create. On this basis Croce attempts to reconcile the opposition between the idealist foundations of nineteenth-century European thought and the materialist conception of history - an opposition which had been introduced by Marx and Engels in 1845/46, in their chapter on Feuerbach in The German Ideology. Although during their lifetime the relevant passages of the work had never been published, their critique of what they called the "Hegelian system" became the basis of the modern Marxist conception of history.

Rather than understanding "history of freedom" in an abstract fashion and as a deterministic teleological development, for Croce the "rationalisation and idealisation of historical forces in relation to the concept of freedom" ${ }^{\text {"No }}$ is a natural consequence of the capacitating forces of the enlightenment, in Kantian terms the consequence of the liberation from self-incurred tutelage. In this sense Croce's concept resembles Moses Mendelssohn's explanation of the enlightenment as a "modification of societal life" which affects "people's efforts and strivings to improve their societal existence". Aufklärung, for Mendelssohn, is "vernünftiges thinking about the things of human life". ${ }^{51}$ Hegel develops his concept of freedom in the Philosophy of Right, explaining it as "ethical life" in the "existing world" ${ }^{2}$ For Croce, freedom is not so much a historical reality but a way of thinking the past:

"Historical sentiment and liberal sentiment are indivisible, to the extent that history can't be defined in any better way than as 'history of freedom', because this is the only way to give it a sense and to make it intelligible. No doubt that in history we also find theocratic and autocratic regimes, violent

${ }^{50}$ G. Galasso, "Nota del Curatore", in B. Croce, Storia d'Europa nel secolo XIX (Milan: Adelphi, 1991), 451.

${ }^{51}$ M. Mendelssohn, “Ueber die Frage: Was heißst aufklären?”, in: Schriften zur Philosophie, Aesthetik und Apologetik (Hildesheim: Olms, 1968), 2: 246-50, 246 f.

On Croce's concept of history as the history of freedom Emanuele Cutinelli Rèndina, "Nota introduttiva", in Croce - Mann, Lettere 1930-36 (Naples: Flavio Pagano, 1991), XIII-XXV.

${ }^{52}$ Hegel, Grundlinien der Philosophie des Rechts, 142, (\$142). The Philosophy of

Right is here more relevant than the Philosophy of History. 
regimes and reactions, counterreformation, dictatorships and tyranny; but what always resurges, proceeds and develops is freedom". 53

Obviously, Croce makes a difference between the past and history, whereby history is only the past made by man and historical reality a condition of the mind, an intellectual reconstruction of the past. ${ }^{54}$ As Max Scheler explained, this capacity to reflect in abstract terms about humanity's existence, outside a specific historical context, represents a fundamental anthropological characteristic of man's cosmological experience. ${ }^{55}$ For Croce "the historical sentiment coincides with the European sentiment". It is with reference to the new semantic of time, observed in the discourse of recent ideological currents, where Croce identifies a dangerous departure from the European tradition. ${ }^{56} \mathrm{His}$ argument is directed against any form of authoritarian nationalism, as it came to prevail in Europe since the late 19th century. This concern about the ideological transformation within nationalist thought shares common ground with that of another great historian of his time, Friedrich Meinecke, the author of Weltbürgertum und Nationalstaat. ${ }^{57}$

In this context it is revealing that Croce's Storia d'Europa also provides an early version of the theory of the German Sonderweg, ${ }^{58}$ a devastating account of the historical evolution of the German sense of liberty since the Reformation, which led to

${ }^{53}$ Croce, Antistoricismo, 33.

${ }^{54}$ B. Croce, Teoria e Storia della storiografia (Milan: Adelphi, 1989), 84, 105. See

also G. Galasso, Croce, Gramsci e altri storici (Milano: Saggiatore, 1978), 12.

${ }^{55}$ M. Scheler, Die Stellung des Menschen im Kosmos (1928) (Bern / München:

Franke, 1983).

${ }^{56}$ Croce, Antistoricismo, 34.

${ }^{57}$ Croce refers directly to Meinecke's book: Teoria e Storia, 341. On Croce and

Meinecke see F. Tessitore, "Meinecke in Italien”, in: Friedrich Meinecke in seiner

Zeit. Studien zu Leben und Werk, eds G. Bock / D. Schönpflug (Stuttgart: Steiner, 2006), 227-256.

${ }^{58}$ Croce speaks about una "delineazione storica" of Germany: B. Croce, "Il dissidio spirituale della Germania con l'Europa" (1943) in: Croce - Mann, 43-65, 59. For an English version of his writings on the topic see B. Croce, Germany and Europe. A spiritual Dissension (New York: Random House, 1944). 
a liberation of the spirit and of critical scientific enquiry, but at the same time introduced a cult of the prince and the state, which, in Croce's view, ultimately divorced the freedom of the spirit from that of politics. Pointing to Croce's theory of a German Sonderweg is important not only because it has certain implications for his view of "Italian Fascism as an eclipse", but also because it demonstrates that his concept of history as the history of freedom did not blind him for critical evaluations of teleological concepts of history. Exemplified by his evaluation of the Revolution of 1848 , for Croce the German people seemed incapable of a true liberal transformation. German national sentiment was never fused with the ideal of political liberty, as it became the rule for other peoples during the nineteenth century. The reasons for this are not to be found in racial determinism, but in the people's historical development.

Thomas Mann, to whom Croce dedicated his History of Europe, was able to identify with this analysis. In his initial response to Croce's Antistoricismo, Mann defended Nietzsche's critique of historicity on the basis that German historicism has had a particularly weakening effect on life; but then he explains that Nietzsche's antistoricismo had to be read within its particular historical context, whereas "now it is at the order of the day to reconstitute what is essential to the sense of history, defined as civiltà e cultura." ${ }^{59}$ Despite his critical account of Germany's emergence as a modern nation state, Croce initially refused to give up his belief that Germany, within a wider context of European culture, had the capacity of constructing a more developed sense of civiltà. He pointed to a vital connection between the development of German and European culture, to the extent that Europe is deeply indebted to Germany for the theoretical conceptualisation of its notion of liberty. However, Germany's spiritual-political development had brought it into a deep opposition to Europe as a whole. Meanwhile, Croce understood his account of "storia prussiana, bismarckiana, treitschkiana, nazionalistica ecc non certamente favorevoll" as the source of his critical reassessment of Italy's own national history. ${ }^{60}$ Only later, under the impression of the unimaginable brutality of the German occupation of Italy, he lost his hope that the immense "spiritual dissent" which separates Germany from Europe could ever be bridged, if not through the construction of a united Europe, in which Germany will finally find its place "not as barbaric master and torturer, but as

${ }^{59}$ Thomas Mann to Benedetto Croce, 28.9.1930, in Croce - Mann, 69. Both authors contributed to the volume Freedom. Its Meaning, ed. R. Nanda Anshen (New York: Harcourt, Brace, 1940). On the relationship Croce-Mann see also the short passages in Klaus Mann, "Begegnungen mit Croce and Sforza" (1945), in: idem, Auf verlorenem Posten. Aufsätze, Reden, Kritiken, 1942-1949. Hamburg: Rowohlt, 1994, 180-190; and Schneider, "Eine überaus eindrucksvolle Begegnung".

${ }^{60}$ Croce to Mann, 6.12.1931, in: Croce-Mann, 5 
one people among other peoples, as one of the strongest in the race which defines the life of mankind and of civilisation." 61

As mentioned earlier, Croce's rejection of positivism was at the origin of his interest in Hegel. Like Hegel, Croce placed history at the centre of his new humanism, but his was an "absolute historicism", a history without God. While taking account of man's capacity to reason, he rejects the notion of abstract reason in the Hegelian sense. In particular, his idealism is not a force which provokes changes in the course of history through the invention of artificial utopias. Thus, he questioned the Enlightenment's belief in humankind as well as Hegel's faith in progress. It was on this basis that Croce continued to take account of materialist forces in a Marxist sense and that he developed a lively interest in those exponents of European social theory, which seemed to be able to explain social and economic phenomena in a non-positivistic fashion and without recurrence to simplistic laws of social development. He read Simmel and Durkheim, and initiated Italian editions of Max Weber's and Walter Rathenau's works through his publisher Laterza. Meanwhile, he also engaged with the neo-Kantian Windelband; with Dilthey, whose theory of Geisteswissenschaft claimed the identity of subject and object in historical research; and he showed an early interest in Freud's Die Traumdeutung, at a time when the Viennese was still largely unknown among Italian social scientists. ${ }^{62}$ With the help of social theory Croce hoped to identify the material conditions of historical processes, without recurring to the positivism of Italy's more conventional social scientists.

${ }^{61}$ Croce, "Il dissidio spirituale della Germania con l'Europa", 61. Croce's reaction to

Meinecke's Die Deutsche Katastrophe should be considered in this context: Tessitore, "Meinecke in Italien", $235 \mathrm{f}$.

${ }^{62}$ D. Coli, Croce, Laterza e la cultura europea (Bologna: il Mulino, 1983), 69 ff, 8290. H. White, Metahistory. The historical imagination in nineteenth-century Europe (1973) (Baltimore: Johns Hopkins University Press, 1975), 381 f. R. Vivarelli, Storia delle origini del fascismo. L'Italia dalla grande guerra alla marcia su Roma (Bologna: il Mulino, 1991), 2:115 f. For Dithey’s concept of Geisteswissenschaften see W. Dilthey, Der Aufbau der geschichtlichen Welt in den Geisteswissenschaften (Göttingen: V\&R, 1958), 278. For the concept of "absolute historicism” see D. D. Roberts, Benedetto Croce and the Uses of Historicism (Berkeley: University of Los Angeles Press, 1987), 4. 
Croce's engagement with social theory became the basis for his reconciliation between materialism and idealism, a concept of history which closely resembled Benjamin's revision of historical materialism. For Croce there is a material and political dimension to the life of the mind, which the historian has to take account of. As Giuseppe Galasso explained, "for Croce spiritualism does not mean the abstract idealisation of certain factors of the historical process... It only means the affirmation of a gnoseology and of a logic, which aims at pushing the transcendental premises of classical-Hegelian idealism to the extreme. Therefore, human reality, as subject and object, covers everything which is known or which can be known. For the reality of man, as subject or object, the only adequate way of knowing is historical." ${ }^{" 3}$ For Croce, this knowing was subjective and presentist. At the time historical materialism represented for Italians the dominating approach to historical research, most famously represented by the historian Gaetano Salvemini, who is today mostly remembered as a Socialist and anti-Fascist politician. Marxism influenced Italy's philosophical debate well beyond the often rather narrow readings of the Labour movement, spreading even to Gentile and Volpe, who later aligned themselves with Fascism. ${ }^{64}$ For Croce, historical materialism became the basis for a realistic concept of history that considered the economic base as an objective parameter of historical change. Meanwhile, his idealism and his historical consciousness stood against the simplistic construction of future oriented teleologies based on the positivist reading of social phenomena. Conceptualized as a "philosophy of practice", Croce's synthesis between idealism and materialism presents the most important conception of historical time since Hegel and Marx.

This "philosophy of praxis" had a direct impact on the ways in which Italy addressed the experience of modernity, and of World War One in particular. Antonio Gramsci's intellectual crusade against the Left's deterministic attendismo in the face of fascism can't be explained without reference to Croce. ${ }^{65}$ His critique of positivistic materialism

${ }^{63}$ Galasso, Croce, 13.

${ }^{64}$ On the assimilation of European thought in Italian Marxism R. Drake, Apostles and Agitators: Italy's Marxist Revolutionary Tradition (Cambridge, Mass.: Harvard University Press, 2003). R. Zangheri, Storia del Socialismo Italiano (Turin: Einaudi, 1997), 2:337 sq. On the relationship between Socialism and liberal principles see also G. De Ruggiero, The History of European Liberalism (Oxford: Oxford University Press, 1927), 391 sq.

${ }^{65}$ On Gramsci's understanding of the concept see A. Gramsci, Quaderni del Carcere, ed. V. Gerratana (Turin: Einaudi, 1975), 3:1583. For the general context see Gentile, The Struggle for Modernity, 1, 41 f. Roberts, Benedetto Croce, 11. M. Clark, Antonio 
started from Croce's idealism, understood as a subjectivist conception of history. ${ }^{66}$ For Gramsci the belief in any rational development of history was at the root of the attendismo with which he wished to break. The logic behind such erroneous conceptions of history was the storm which rushed humanity into catastrophe.

While both Croce and Gentile arrived at their respective positions through a revision of Hegelian doctrine, Gentile's absorption of the individual in the State resulted in "the annihilation of individual autonomy and liberty", the contrary of Croce's own concept of freedom. ${ }^{67}$ Due to his failure to acknowledge the relationship between the crisis of Liberalism and the advent of Fascism, Croce's History of Italy and his History of Europe have rightly been challenged by post-war historiography, reversing their initial importance since the 1920s. Initially, like many Italian liberals, Croce saw (and underestimated) Fascism as a reaction to the threat of a Socialist revolution. Soon he came to understand Fascism as the antithesis of liberal Italy. Contrary to Croce, for Gramsci Fascism was the natural consequence of the social conflicts liberal Italy had itself generated, a position which became almost canonical among post-war historians. If Croce depicted Fascism as a parenthesis in the history of Italy it was primarily an attempt to reject the Fascists' own claims of a logical continuity between

Gramsci and the Revolution that Failed (London / New Haven: Yale University

Press, 1977), 48. M. Martelli, Etica e storia. Croce e Gramsci a confronto (Naples:

Istituto Italiano per gli studi filosofici, 2001), 11. F. Capucci, Antonio Gramsci. Il materialismo storico e la filosofia di Benedetto Croce (L'Aquila: Japache, 1978), 30

f. On the European dimension in Gramsci's thought also N. Tranfaglia, La Prima

Guerra mondiale e il fascismo (Turin: UTET 1995), 220.

${ }^{66}$ Capucci, Antonio Gramsci, 29. See also B. Croce, La mia Filosofia (Milano:

Adelphi, 1993), 21.

${ }^{67}$ G. Casale, Benedetto Croce between Naples and Europe (New York: Peter Lang, 1994), 118. 
the Risorgimento and Fascism. ${ }^{68}$ Confronted with the Fascists' claims, Croce wished to protect the reputation of the liberal period (and the years of Giolitti's governments in particular). At the end of the war the same argument served Italy to convince the Allies that there were differences between German National socialism (understood to be deeply rooted in German history) and Italian Fascism (presented as having little to do with the glorious tradition of the Risorgimento and the liberal nation state).

Despite the inherent inconsistencies of this theory, Croce's History of Italy and his History of Europe were born out of his own opposition to Fascism. In their time they presented themselves as empirical applications of a theoretical conceptualisation of historical time, which in itself formed a synthetic product of Europe's political and intellectual life between the end of the nineteenth and the early twentieth century, standing alongside his treatises on aesthetics and literature as a defence of European culture in the face of Fascism. Belonging to the intellectual milieu which Zweig described as The World of Yesterday, Croce collaborated during those years with André Gide, Aldous Huxley, Heinrich Mann, Romain Rolland, Jean Cocteau, Boris Pasternak and many others for Klaus Mann's anti-Fascist periodical Die Sammlung, representing a Europe which refused to surrender its humanist values. ${ }^{69}$

${ }^{68}$ On the critique of the "parenthesis" argument see P. Corner, "Liberalism, Pre-

Fascism, Fascism", in Rethinking Italian Fascism. Capitalism, Populism and Culture. ed. D. Forgacs (London: Lawrence and Wishart, 1986), 11-20, 12 and R. J. B.

Bosworth, The Italian Dictatorship. Problems and perspectives in the interpretation of Mussolini and Fascism (London: Arnold 1998), 45 f. For Gramsci’s critique of Croce see J. A. Davis, “Introduction”, in Gramsci and Italy's Passive Revolution, ed. idem (London: Croom Helm, 1979), 11-30, 13. For the context of this historiographical debate see also R. Vivarelli, Il fallimento del liberalismo. Studi sulle origini del fascismo (Bologna: il Mulino, 1981), 170.

${ }^{69}$ Roberts, Benedetto Croce, 6. Agazzi, "Benedetto Croce”. Momigliano “Benedetto Croce”. Coli, Croce, 61 sq., 93. E. Garin, La cultura italiana tra '800 e '900 (Bari: Laterza, 1962), 155-74. Although his analysis differs from Croce's, another exponent of Italy's idealist anti-Fascism was Guido de Ruggiero. His History of European Liberalism (1924), translated by Collingwood in 1927, provides an important key to 
This intellectual context makes it difficult to reduce Croce's role in European thought to his view of Fascism as an eclipse within the development of liberal Italy. In

Galasso's words, the History of Europe was "a political polemic", which held European values up against "the totalitarianism and nationalism" of the present political situation and against "the decadence and the irrationalism" of its cultural life. ${ }^{70}$ It was a product of Croce's own experience of historical time as crisis.

How close Benjamin's concept of history is to that of Croce has been noted (but not further explored) by Stéphane Mosès in his L'Ange de l'Histoire. The transformation of the past depends on the present of the historian, which both authors experienced in similar ways. ${ }^{71}$ Like in the case of Croce, also for Benjamin the positivism of the social and historical sciences was an important target of his new concept of historical time. ${ }^{72}$ Moreover, what Benjamin and Croce shared was their pluralistic view of the past as a way to counter simplistic teleologies of history. Meanwhile, both acknowledged the conceptual roots of their approach in historical materialism. They developed their theories of history on the contemplative basis of their own historicalempirical research: Croce published his Storia dell'eta barocca in Italia in 1929, the same year Benjamin's Ursprung des deutschen Trauerspiels appeared as a book, a work which anticipates several important elements of Über den Begriff der Geschichte. ${ }^{73}$ Benjamin's Paris of the Passagenwerk was Croce's Naples. In Ursprung des deutschen Trauerspiels, partly written in Croce's own backwater, on Capri, Benjamin quoted at length from Croce's Aesthetic. Discussing Croce's critique of "genre" as an artificial scheme of aesthetic classification leads Benjamin to reject a history of ideas conceived as a "pseudo-logical continuum", following simplistic

the crisis of liberalism. See R. Bellamy, Rethinking Liberalism (London: Pinter,

2000), chpt.3.

${ }^{70}$ Galasso, "Nota del Curatore", 451.

${ }^{71}$ Mosès, Der Engel, 87 f, 134. B. Croce, La storia come pensiero e come azione

(Bari: Laterza, 1938), chpt.2. On the relationship Benjamin-Croce-Gramsci see also P. Ives, Gramsci's Politics of Language. Engaging the Bakthin Circle and the Frankfurt

School (Toronto: University of Toronoto Press, 2004).

72 Tiedemann, "Studien zur Philosophie Walter Benjamins”, 148.

${ }^{73}$ R. Tiedemann, “Zwei Schulaufsätze”, in: idem., Mystik und Aufklärung, 299-309, 304. 
teleological schemes of historical development. ${ }^{74}$ In this they both went against the established scholarly orthodoxies of Geistesgeschichte. But the point here is not to establish to what extent Benjamin was influenced by Croce. Instead, what matters is the fact that it was the experience of time as crisis which led both authors to develop a new concept of history and to reconsider the relationship between materialism and idealism.

This parallel analysis of Croce's and Benjamin's theory of history is an attempt to understand the crisis of the early twentieth century as a short but crucial moment of change in the semantic of historical time, with major implications for the philosophical foundations of modern European thought. Arguing from a number of very different perspectives, historians and cultural commentators from Theodor W. Adorno to Alan Milward (among many others) have understood the post-war period in terms of Restoration, questioning the extent to which 1945 represents a new beginning or a Stunde Null. The same pattern of reinstatement seems to apply to the way cultural theorists after 1945 have dealt with the relationship between idealism and materialism as a way of conceptualising historical time and the experience of modernity. As soon as the moment of crisis had passed - as far as the trauma of the war and the Shoah ever passes - European thought returned to think within established orthodoxies. Croce's work largely disappeared into oblivion - at least outside Italy and outside the specialized debates of philosophers. During Benjamin's the first renaissance, in the 1960s, commentators made him the object of passionate fights between different factions of Marxists, before the emphasis on the theological component of his work gained wider resonance. Koselleck's studies on the semantics of historical time offer a new context to read both Croce and Benjamin as part of a general rethinking of the social and cultural sciences.

\footnotetext{
${ }^{74}$ W. Benjamin, Ursprung des deutschen Trauerspiels, in: Gesammelte Schriften, I.1
}

(Frankfurt / M.: Suhrkamp, 1991), 203-409, here 223-227. 